\title{
Influence of Chopped Basalt Fibers on the Shear Strength of RC Beams without Stirrups
}

\author{
Seyit Ziya MAZHARI ${ }^{1}$ and Güray ARSLAN ${ }^{2}$
}

\begin{abstract}
This research studied the influence of chopped basalt fibers (BFs) on the shear strength of reinforced concrete (RC) beams without stirrups. The beams including one reference and three basalt fiber reinforced concrete (BFRC) beams were tested under concentrated load at mid-span to determine the shear strength. The test parameters are volume fraction of basalt fibers $\left(\mathrm{V}_{\mathrm{f}}\right)$ and shear span-to-effective depth ratio $(\mathrm{a} / \mathrm{d})$ of beam. The deflection of the beam and the cracking pattern were monitored during the test at certain stages of the monotonic loading until failure. It is observed that the contribution of BFs to the shear strength at the ultimate state decreases as volume fractions of BFs increase from $0 \%$ to $1.5 \%$.
\end{abstract}

Keywords-Reinforced concrete, beam, chopped basalt fibers, shear strength, deflection.

\section{INTRODUCTION}

$\mathrm{N}$ owadays using fiber reinforced concrete (FRC) in structural members has been increasing significantly. It has been well established that the addition of fibers can augment the mechanical behavior of plain concrete such as flexural strength, deformation capacity, impact resistance, compressive and tensile strength, load capacity after cracking, fatigue and abrasion strength, toughness and shrinkage [1-11].

Recently, basalt fibers (BFs) has gained popularity due to some advantages like no additives which makes it cheaper, good insulation characteristic, environmentally friendly manufacturing process, commercial availability, good resistance to chemical attack and temperature, high modulus, sound isolation, low moisture absorption, non-toxic, crack resistance, crack control, vibration resistance, durability and above all excellent interfacial shear strength [11-17] and become a good alternative as a potential competitor in reinforced concrete (RC) applications.

Despite there are considerable studies about FRC, there is limited fundamental research on the effects of chopped BFs on the shear strength of RC beams. Issa et al. [18] observed significant improvements in the shear strength of RC beams with insufficient shear reinforcement strengthened with BF reinforced polimer. Dias and Thaumaturgo [9] investigated the relationship between the mixing value of fiber and fracture toughness of geopolymeric cement reinforced with BFs and they demonstrated that geopolymer cement reinforced with

Seyit Ziya MAZHARI ${ }^{1}$ is with the Institute of Natural and Applied Sciences, Yildiz Technical University, Istanbul, 34220 TURKEY

Guray ARSLAN ${ }^{2}$, was with Civil Engineering Department, Yildiz Technical University, Istanbul, 34220 TURKEY
BFs exhibited more displacement and more fracture toughness.

The main objective of this paper is to evaluate the shear strength of basalt fiber reinforced concrete (BFRC) beams without stirrups which were tested under concentrated load at mid-span. The deflections of the beams and their cracking patterns were monitored at the certain stages of the monotonic loading until failure. The test parameters are the volume fraction of basalt fibers $\left(\mathrm{V}_{\mathrm{f}}\right)$ and shear span-to- effective depth ratio $(\mathrm{a} / \mathrm{d})$ of beam.

\section{TEST SPECIMENS}

A combination of letters and numbers is used for specimen labels "C" followed by the shear span-to-effective depth ratio to denote all test specimens in this research and "B" followed by the volume fraction of BFs. For example, a beam having a shear span-to-effective depth ratio of 2.5 and with a volume fraction of fibers equal to $1.5 \%$ is labeled as $\mathrm{C} 2.5 \mathrm{~B} 1.5$. The specimen labelled as $\mathrm{C} 2.5 \mathrm{R}$ is the reference beam that do not contain any fibers.

The tests were carried out to evaluate the contribution of BFs to the shear strength of RC beams. All beams have the same cross- sectional dimensions $150 \mathrm{~mm} / 240 \mathrm{~mm}(\mathrm{~b} / \mathrm{h})$ with an effective depth of $210 \mathrm{~mm}$, and a constant tensile reinforcement ratio $(\rho)$. Four different volume fractions of basalt fibers as $0 \%, 0.5 \%, 1.0 \%$ and $1.5 \%$ were considered.

Three-point loading tests were conducted to identify the ultimate load capacities of beams using a displacement controlled loading machine and the beams were monitored during the test. The geometrical properties of test specimens are shown in Fig. 1.

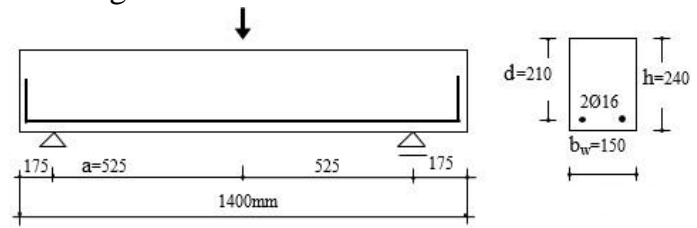

Fig. 1 Geometry and flexural reinforcement of beams

The tensile strength and the elasticity modulus of BFs are $4840 \mathrm{MPa}$ and $90 \mathrm{GPa}$, respectively. The characteristics of BFs are reported as the application limit temperatures are \pm $980^{\circ} \mathrm{C}$, the specific weight is $2.60-2.80 \mathrm{gr} / \mathrm{cc}$, the fiber diameter is $9-23 \mu \mathrm{m}$ and the length of fibers is $12 \mathrm{~mm}$. This physical and mechanical properties of BFs, provided by the manufacturer. 
Reinforcement schemes of the test specimens are shown in Figure 1, the characteristics of beams are shown in Table 1, where $f_{c}$ is the compressive cylinder strength of concrete and 1 is the length of beam.

The beams were loaded until either failure or the load dropped below approximately $80 \%$ of its maximum value.

TABLE I

PROPERTIES OF BEAMS

\begin{tabular}{|l|c|c|c|c|c|c|}
\hline \multicolumn{1}{|c|}{ Beams } & $\begin{array}{c}\mathrm{f}_{\mathrm{c}} \\
(\mathrm{MPa})\end{array}$ & $\begin{array}{c}\mathrm{V}_{\mathrm{f}} \\
(\%)\end{array}$ & $\begin{array}{c}\rho \\
(\%)\end{array}$ & $\mathrm{a} / \mathrm{d}$ & $\begin{array}{c}\mathrm{a} \\
(\mathrm{mm})\end{array}$ & $\begin{array}{c}1 \\
(\mathrm{~mm})\end{array}$ \\
\hline $\mathrm{C} 2.5 \mathrm{R}$ & 24.85 & --- & 1.28 & 2.5 & 525 & 1400 \\
\hline $\mathrm{C} 2.5 \mathrm{~B} 0.5$ & 16.94 & 0.5 & 1.28 & 2.5 & 525 & 1400 \\
\hline $\mathrm{C} 2.5 \mathrm{~B} 1.0$ & 12.37 & 1.0 & 1.28 & 2.5 & 525 & 1400 \\
\hline $\mathrm{C} 2.5 \mathrm{~B} 1.5$ & 6.29 & 1.5 & 1.28 & 2.5 & 525 & 1400 \\
\hline
\end{tabular}

\section{EXPERIMENTAL RESULTS}

The failure of all beams occurred in shear. First, vertical flexural cracks was observed around the mid-span of all beams as predicted. With the increase in load, new flexural cracks were formed at a distance of mid-span area. In the last stage, vertical flexural cracks appeared around the mid-span started to proceed towards the loading point. Crack patterns are shown in Fig 2-5.

Test results are given in Table 2 below, $\mathrm{P}_{\text {co }}$ is the peak load of beam obtained experimentally, $\mathrm{P}_{\mathrm{u}}$ is the ultimate load that is assumed to be equal to $80 \%$ of $\mathrm{P}_{\mathrm{co}}, \square_{\mathrm{co}}$ and $\square_{\mathrm{u}}$ are the deflection at the peak load and the ultimate deflection of each beam, respectively, and the dissipated energy is the area under the load-deflection curve.

TABLE II

EXPERIMENTAL LOAD AND DEFLECTION VALUES OF BEAMS

\begin{tabular}{|l|c|c|c|c|c|c|}
\hline \multicolumn{1}{|c|}{ Beams } & $\begin{array}{c}\mathrm{P}_{\mathrm{co}} \\
(\mathrm{kN})\end{array}$ & $\begin{array}{c}\mathrm{P}_{\mathrm{u}} \\
(\mathrm{kN})\end{array}$ & $\begin{array}{c}\delta_{\mathrm{co}} \\
(\mathrm{mm})\end{array}$ & $\begin{array}{c}\delta_{\mathrm{u}} \\
(\mathrm{mm})\end{array}$ & $\begin{array}{c}\delta_{\mathrm{u}} / \\
\delta_{\mathrm{co}}\end{array}$ & $\begin{array}{c}\text { Dissipated } \\
\text { Energy } \\
(\mathrm{kNm})\end{array}$ \\
\hline $\mathrm{C} 2.5 \mathrm{R}$ & 84.93 & 67.94 & 5.12 & 6.76 & 1.32 & 0.3365 \\
\hline $\mathrm{C} 2.5 \mathrm{~B} 0.5$ & 84.02 & 67.21 & 5.06 & 5.66 & 1.12 & 0.2469 \\
\hline $\mathrm{C} 2.5 \mathrm{~B} 1.0$ & 72.43 & 57.94 & 3.90 & 5.18 & 1.33 & 0.1528 \\
\hline $\mathrm{C} 2.5 \mathrm{~B} 1.5$ & 55.81 & 44.65 & 5.16 & 5.76 & 1.12 & 0.1851 \\
\hline
\end{tabular}

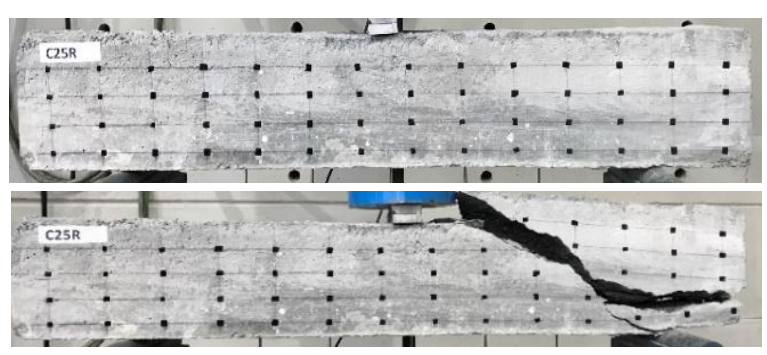

Fig. 2 Crack Pattern of C2.5R

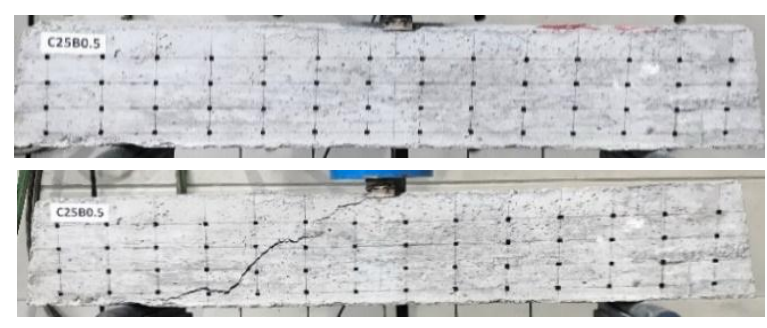

Fig. 3 Crack Pattern of C2.5B0.5

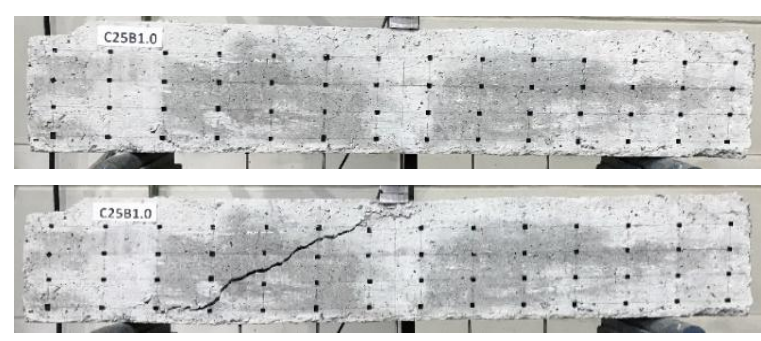

Fig. 4 Crack Pattern of C2.5B1.0

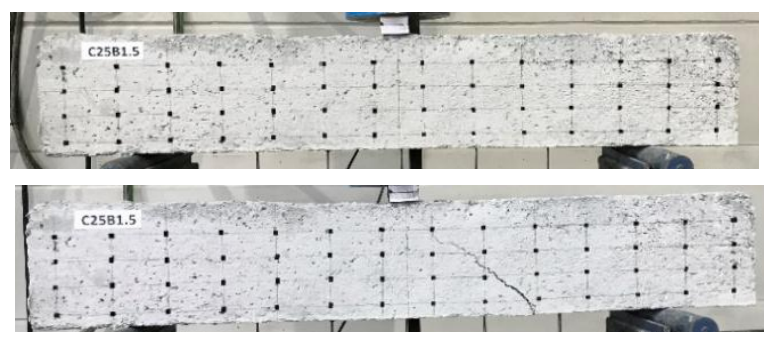

Fig. 5 Crack Pattern of C2.5B1.5

\section{COMPARISON OF LOAD-DEFLECTION RELATIONSHIPS OF BEAMS}

The load-deflection curves of beams are shown in Figure 6. It is deduced that:

The beam having BFs in the amount of $0.5 \%$ by volume reached a maximum load similar to the load reached by the reference beam, then the load decreased rapidly while a certain amount of deflection of the reference beam was observed beyond the maximum load without a significant loss in the load-carrying capacity.

Introducing BFs in the amount of $1.0 \%$ by volume resulted in significant decreases in the load-carrying and deflection capacities. The load-carrying capacity was reduced by approximately $15 \%$ and the maximum load was reached at a mid-span deflection approximately $\% 25$ less than that of the reference beam.

The addition of BFs in the amount of $1.5 \%$ by volume also reduced the load-carrying capacity, $34 \%$ compared to the capacity of the reference beam, but the mid-span deflection under the maximum load was similar to that of the reference beam.

By comparing four beams, it is observed that increasing the amount of BFs causes deterioration on both load-carrying capacity of beams and the compressive strength of concrete $\left(f_{c}\right)$. 


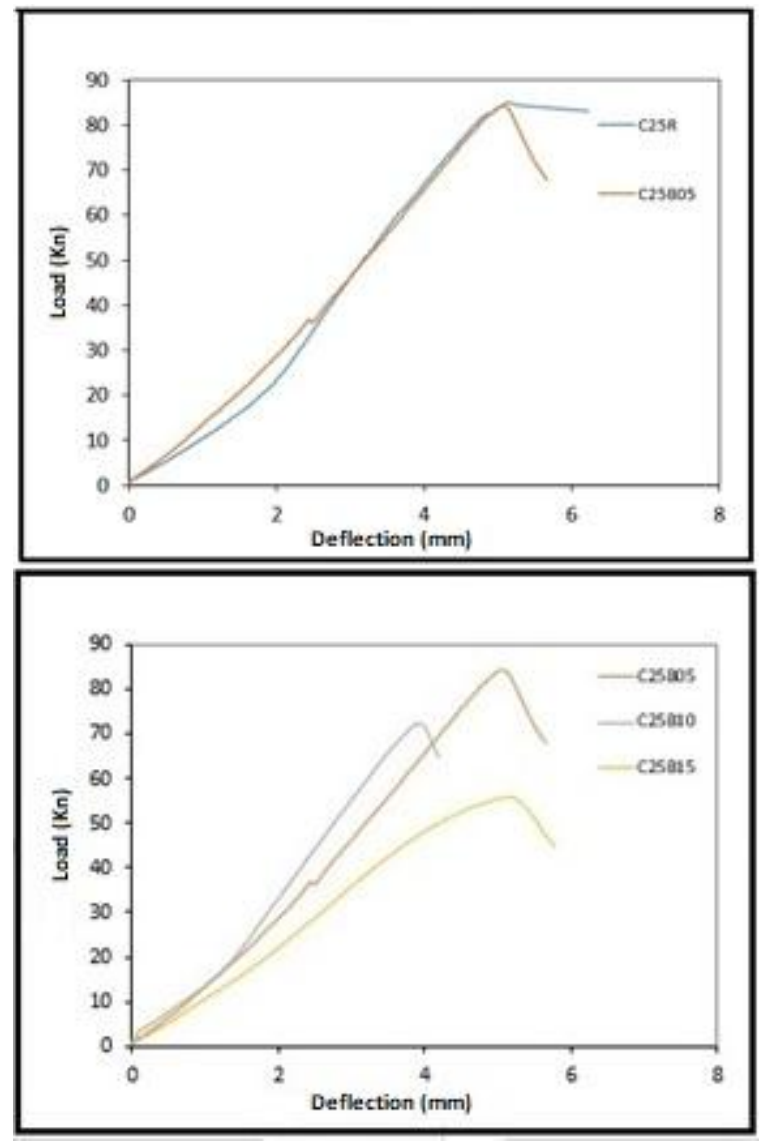

Fig. 6 Load-deflection curves

\section{V.CONCLUSION}

According to the test results in this study, it is observed that the addition of basalt fibers was not able to improve the strength and ductility of RC beam. Contrarily, it resulted in a behavior poorer than the behavior of reference beam. This can be attributed to the inadequate bonding between aggregate and concrete due to the adhering of basalt fibers to aggregate while mixing the fibers with concrete.

\section{REFERENCES}

[1] S.A. Ashour, G. S. Hasanain, F. F. Wafa, "Shear behavior of highstrength fiber reinforced concrete beams," ACI Struct J, Vol. 89, no. 2, pp. 176-184, 1992.

[2] K. Noghabai, "Beams of fibrous concrete in shear and bending: experiment and model," ASCE J of Struct Eng, Vol. 126, no. 2, pp. 243-251, 2000. https://doi.org/10.1061/(ASCE)0733-9445(2000)126:2(243)

[3] F. Majdzadeh, M. Soleimani, N. Banthia. "Shear strength of reinforced concrete beams with a fiber concrete matrix," Can J Civ Eng, Vol. 33,pp. 726-734, 2006. https://doi.org/10.1139/105-118

[4] E. Mondo "Shear capacity of steel fibre reinforced concrete beams without conventional shear reinforcement," Royal Ins. of Tech, Vol. 331, pp. 1103-4297, 2011.

[5] N. Kabay. "Abrasion resistance and fracture energy of concretes with basalt fiber," Constr Build Mater, vol. 50, pp. 95-101, 2014. https://doi.org/10.1016/j.conbuildmat.2013.09.040

[6] M.T. Borhan. "Thermal and mechanical properties of basalt fibre reinforced concrete," World Acad Sci Eng Tech, Vol. 76, pp.313-316, 2013.
[7] G. Arslan, "Shear strength of steel fiber reinforced concrete (SFRC) slender beams." KSCE J Civ Eng, Vol. 18, no. 2, pp. 587-594, 2014. https://doi.org/10.1007/s12205-014-0320-x

[8] G. Arslan, R.S.O Keskin, M. Ozturk."Shear behaviour of polypropylene fibre-reinforced-concrete beams without stirrups," Proc Inst Civ Eng Struct Build, Vol. 170, no. 3,pp. 190-198, 2017. https://doi.org/10.1680/jstbu.16.00202

[9] P.D. Dias, C. Thaumaturgo. "Fracture toughness of geopolymeric concretes reinforced with basalt fibers." Cem Conc Comp, vol. 27, no.1, pp. 49-54, 2005. https://doi.org/10.1016/j.cemconcomp.2004.02.044

[10] R. Narayanan and I. Y. S. Darwish "Use of steel fibers as shear reinforcement," ACI Struct J, Vol. 84, No. 3, pp. 216-227. 1987.

[11] J. Branston, D. Sreekante, S. Y. Kenoo, C. Taylor, "Mechanical behavior of basalt fibre reinforced concrete," Constr Build Mater, vol. 124, no. 3, pp. 878-886, 2016. https://doi.org/10.1016/j.conbuildmat.2016.08.009

[12] M. Di Ludovico, A. Prota, G. Manfredi, "Structural upgrade using basalt fibers for concrete confinement," J Compos Constr Vol. 114, no. 5, pp. 1943-5614, 2010. https://doi.org/10.1061/(ASCE)CC.1943-5614.0000114

[13] V. Fiore, T. Scalici, G. Di Bella, A. Valenza, “ A review on basalt fibre and its composites, "Comp Part B, Vol. 74, no. 4, pp. 74-97, 2015. https://doi.org/10.1016/j.compositesb.2014.12.034

[14] I. V. Borovskich, V. G. Khozin, N. M. Morozov." Sand bazalt-fiber concrete," World App Sci, Vol. 25, no. 5, pp. 832-838. 2013.

[15] C. Jiang, K. Fan, F. Wu, D. Chen, "Experimental study on the mechanical properties and microstructures of chopped basalt fiber reinforced concrete," Mater Des, vol. 58, no. 1, pp. 187-193, 2014. https://doi.org/10.1016/j.matdes.2014.01.056

[16] M.E. Arslan, "Investigation on the effects of basalt fibers on the mechanical properties and fracture energy of ordinary concretes," Pamukkale Univ Civ Eng, Vol. 23, no. 3, pp. 203-208. 2016. https://doi.org/10.5505/pajes.2016.95815

[17] A. B. Kızılkanat, N. Kabay, V. Akyüncü, G. Erdoğan. "Basalt fibers and mechanical properties of basalt fiber reinforced concrete." J Eng Nat Sci, Vol. 32, no. 1, pp. 444-452,2014

[18] M. Issa, T. Ovitigala and M. Ibrahim, "Shear Behavior Basalt Fiber Reinforced Concrete Beams with and without Basalt FRP Stirrups," $J$ Compos Constr, vol. 20, no. 4, pp. 249-260, 2016 https://doi.org/10.1061/(ASCE)CC.1943-5614.0000638. 